Article

\title{
An Evolutionary Approach to Technology Innovation of Cadastre for Smart Land Management Policy
}

\author{
Hae Ok Choi
}

Science and Technology Policy Institute, 508 Building B, Sejong National Research Complex 370, Sicheng-daero, Sejong 30147, Korea; hochoi@stepi.re.kr; Tel.: +82-44-287-2305

Received: 13 January 2020; Accepted: 5 February 2020; Published: 11 February 2020

\begin{abstract}
In this study, we attempted to quantitatively determine the characteristics of keyword networks in the cadastre field using major contents of research drawn from international academic papers. Furthermore, we investigated the macroscopic evolution of cadastral research and examined its keyword network in detail (at a global scale) using semantic analysis. The analysis was carried out based on cadastral-research-related publications extracted from "Scopus" for 1987 to 2019. It was found that cadastre research has closely followed the recent trend of a growing interest in research on geospatial information and standardization. The results showed the advancement of technology innovation within the field of cadastres, as highlighted in the combination of relevant keywords (mostly from those related to spatial information technology and participation of civilians). These new issues are expected to drive the evolution of the academic scope in the future through synthesis with other fields for smart land management policy.
\end{abstract}

Keywords: cadastre; technology innovation; land administration; land management; land-use; semantic analysis; keyword network

\section{Introduction}

The key to understanding the development of modern cadastres is realizing the importance of cadastres in the relationship between humankind and land. With the advent of the digital age, the field of cadastral research has developed through innovations in land management and ownership based on land parcels (2D) and floor plans (3D) [1-5]. Owing to information and communication technology (ICT) advancements, cadastral research has advanced through collaboration with other fields [6,7]. Research shows that the development of cadastral research is strongly correlated with the adaptation of advancements in the information and communication industry in developing countries [8].

In particular, the scope of cadastral research has been enlarged from laws and systems to include geographical-spatial information using new technologies and services. With the help of technological developments, this has changed the previously government-friendly role of cadastres in distinguishing ownership into a more user-friendly role. Thus, to confront the changes such developments will bring to cadastral research and facilitate future studies, there is a need to organize and analyze cadastre studies across various fields. The purpose of this research is to analyze cadastral research evolution from international research papers using semantic analyses (based on macro- and microscopic perspectives) and deduce the flow of research.

A cadastre can be referred to as a register where boundary information is recorded. It also includes the graphical presentation of real property units: the boundaries between plots are determined in order to divide ownership. These boundaries are registered via a digital cadastral map. The registered information, which has legal implications for land use and ownership, is divided into a time series that contains diverse attributes and overlays. As studies on land use [9] or landscape changes [10] have shown, cadastral research is evolving to allow for more elaborate analyses carried out using diverse 
data sources. Regarding the extension of the scope of cadastral research, studies on enhancing the efficiency through social scientific approaches to cadastral research along with those that support the concept of land ownership by following existing laws and institutions [11,12] have been carried out.

Although studies of the application of new technologies for use in cadastral research have continued [13-15], Silva and Stubkjær [8] showed that issues relating to societies, politics, and economics play a significant role in the advancement of cadastral research. In fact, from 1995 to 2020, $18.2 \%$ (1199) of the papers published in the field of cadastral research were categorized as "social science" (scopus.com 28 Jan, 2020). However, as significant technological advancements in cadastral surveying have been made with the adaption of geographical/spatial data and ongoing changes in the data environment (an increase in the availability of public data with open sources), further evolution in this field is predicted.

Cadastral research involves the setting or readjusting of boundaries between real estate areas and is important in the production of legal effects for properties. As cadastral research is related to people and institutions, this study has suggested semantic analyses for the advancement of cadastral research.

Furthermore, global research trends [16-20] and other specific topics have also been analyzed. Research on multiple topics have used bibliometric analysis [21-27]. The review policies and analysis topics focused on using co-authors or co-words [28-34]. Moreover, there is a study that monitored the development process by analyzing trends and issues on specific topics [10,35]. There is also a study on the evolutionary process in the cadastral field [35,36]; however, the study does not discuss the methods for evaluating the evolutionary processes (quantitative analysis or semantic network analysis of major keywords).

\section{Research Methodology}

This research utilizes social network analysis and semantic analysis to investigate the evolution of cadastral research. For the social network analysis, the programs NetMiner and VOS viewer (visualizing scientific landscapes) were used to visualize the network. To examine the microscopic and macroscopic structure of the network aspects, we attempted to visualize the structural changes in the network with respect to time, analyze the centrality index for the entire network, and determine the density for each group.

The search was carried out using the index word "Cadastral," with the analysis period extending from January 1, 1987, to December 31, 2019. Information, including the titles, abstracts, and keywords of the identified papers were extracted.

A social network can be used to understand resource exchanges on the basis of factors such as manpower, institutions, and fields of research [37-40]. Based on a review of previous studies, we designed our methodology and identified the structures of the networks. The centrality index in keyword networks for each group were analyzed and identified through our network analysis, and the density of each group was identified from its networks. Thus, we were able to interpret the networks identified in each group to highlight the current trends in the field of cadastral research.

In this study, we used the following process:

1. Data were extracted from www.scopus.com (3548 papers in total) using the keywords "cadastral" that included major keyword such as "cadastre," "cadastration," and "land administration," which most frequently used words in cadastral fields. Research information was extracted from the following databases: the Web of Science (WoS), SciFiner, and Google Scholar; the functionality of these databases is similar to that of Scopus. Combining these search engines is expensive and time-consuming, and leads to overlapping results. We therefore selected Scopus, which is the most comprehensive database.

We extracted nouns from the data from 1987 to 2019 and generated inter-keyword matrix and inter-network matrix data. 
2. We visualized the evolution of cadastral research using VOS viewer to examine temporal changes in the keyword network.

3. We used social network analysis to group the data, and high-frequency keywords were selected for further consideration.

4. We analyzed high-ranking keywords using centrality index comparisons.

5. Based on institutional network analysis results, we attempted a two-mode network analysis to understand and present institutional relationships.

6. We attempted to understand the intergroup network in detail through group density analysis.

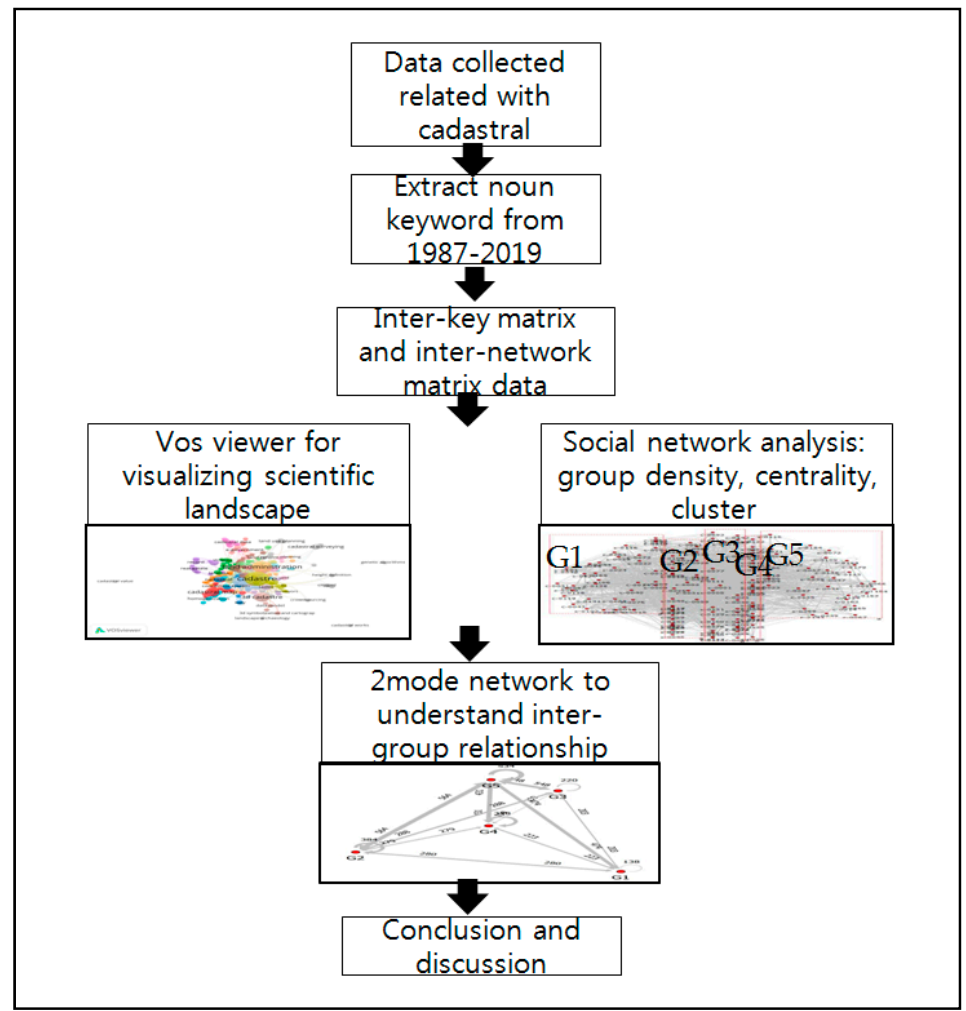

Figure 1. Research process.

NetMiner was used to evaluate the social network analysis evaluating network structure of the keyword network for exploratory analysis and visualization of large network data (netminer.com). VOS viewer was used to map the keyword network as a time series. The distance between the nodes that appear in the network, visualized by NetMiner and VOS viewer [41], represent the intensities of relationships.

Cho and Kim [42] used social networks and data mining to analyze complex relationships between academic fields by extracting the central keywords of each field, along with the connecting keywords used to link different fields. Furthermore, other studies have investigated the structure of knowledge using keywords from diverse academic fields [43-47]. The keywords describe the main topics of academic papers.

The central and connecting keywords are extracted through correlation analysis, and, a network of all keywords is constructed based on the results. This paper presents a linked keyword method that provides a template for building keyword networks using text mining.

We analyzed the keywords extracted from various papers. An intelligent morpheme analyzer was used to preprocess the data, and TI.exe was used to build the network matrix [48-50]. NetMiner was used to build a matrix for network analysis (as visualization of large network data is easier). Network structures were identified by analyzing the group density, the centrality index, and the spring-KK, as 
well as performing a cluster analysis. The characteristics of each network group were also analyzed. As a result, the total number of network links was 2387 , the density was 0.108 , the average degree was 16, and the average distance was 1907. These attribute analysis values represent keywords on the network and help quantify and interpret the relationship between major keywords.

\section{Results}

\subsection{Evolutions Over Time}

To define the official concept of the cadastre, the International Federation of Surveyors established a working group in 1992 to clarify a "The FIG Statement on the Cadastre" [51]. The statement explains the cadastre as an "up-to-date land information system containing a record of interests in land. It usually includes a geometric description of land parcels linked to other records describing the nature of the interests, the ownership or control of those interests, and often the value of the parcel and its improvements." The FIG cadastral concept is shown in Figure 1.

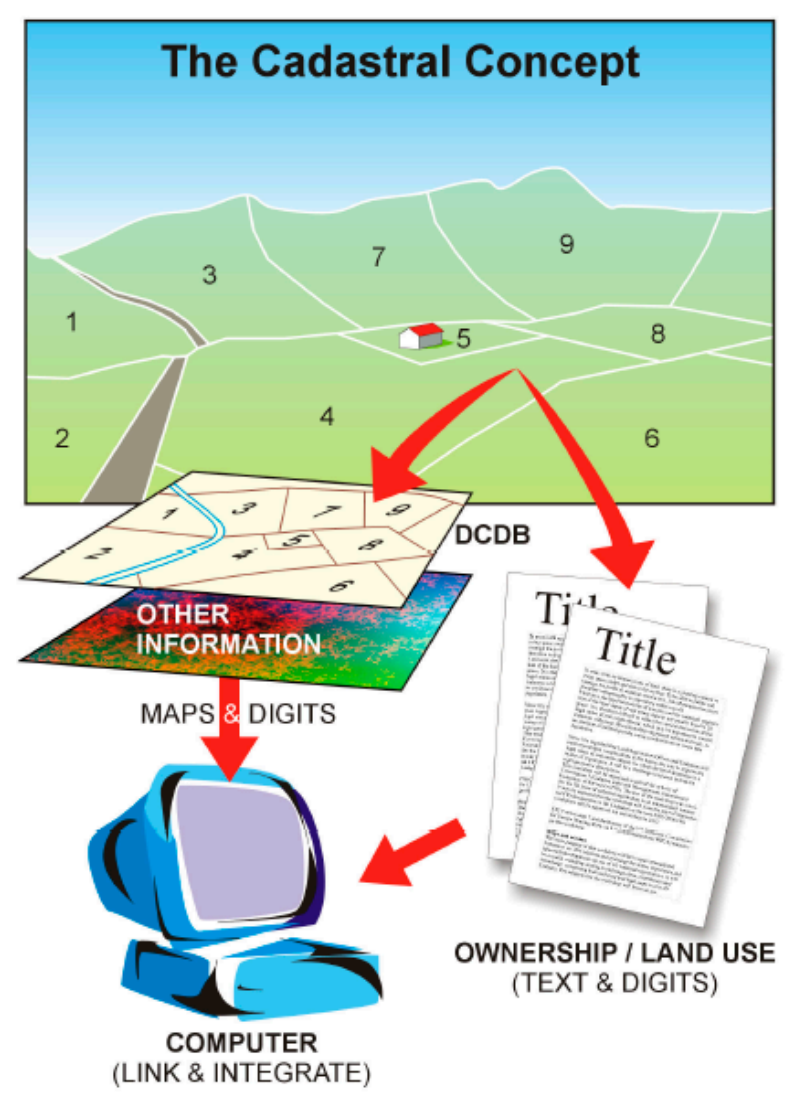

Figure 2. The FIG Statement on the Cadastre [52].

In 1980, the Digital Cadastral Data Base (DCDB) in Figure 2 was formed, and cadastral records were computerized. During the 1990s, land administration improved with the development of the internet. Cadastral maps and cadastral data were developed (alongside other technologies in computing) using the internet after 2000 [52,53].

The first period, before 2001, was characterized by the computerization of cadastral maps through computer programs such as geographic information system (GIS). In the second period from 2002 to 2007, the use of digital cameras in papers relating to land registration steadily increased. In 2005, the cadastral maps of keyword network maps were used as a source of information that integrated various projects led by the government, such as land, real estate, and local operations [30]. In this period, the capacity was developed to manage land, ownership, limits, and obligations; this formed the 
foundation of sustainable improvement [54]. In 2007, volunteered geographical information (VGI) was introduced, which led to a shift from government-led cartography to citizen-led cartography [55-65]. Additionally, the iPhone was introduced in this period, changing people's lifestyles and producing services optimized to individual preferences.

During the third period, which extended from 2008 to 2019, papers related to land administration (based on spatial information) were released. Taking advantage of these developments and to keep pace with globalization, this study attempted to identify the evolution of cadastral research objectively and in a time-sequential manner, by building a knowledge map based on the four periods. The map was divided in accordance with the characteristics of each period to present the limitations and future directions. Scopus provided the keywords for the contents of the study. In this study, the keywords were used to build the keyword network.

In 2008, the global economic crisis led to changes in cadastral policies, providing another opportunity to spread awareness of the importance of land administration and ownership rights. From 2010 , the ability to an update data became the foundation to solve various social problems confronted by cadastres and land administration. In addition, the spatial data based on land administration, along with the open-data policies of governments, provided the opportunity to reconstruct data-based city infrastructures.

1987 to 2001: Figure 3 shows the four major keyword network sections: "cadastre," "sustainable development," "land administration," and "land tenure." The initial studies on cadastres were carried out for real estate, land evaluation, map interpretation, and cadastral maps. In particular, land evaluation and the assessment of land performance using cadastres were the focal points. Williamson [66] considered why the role of the cadastre system was gradually becoming more important to policymakers (particularly in developing countries). This study suggested that the cadastral system adapted the needs of each country such as regularization of land rights and establishment of systems.

Along with the evolution of cadastre and land administration systems [67-70], studies have investigated the expansion of keyword's scope to include land information system (LIS), GIS [71], and spheres relating to new spatial information [72].

administration

cadastral gene

cadastral map

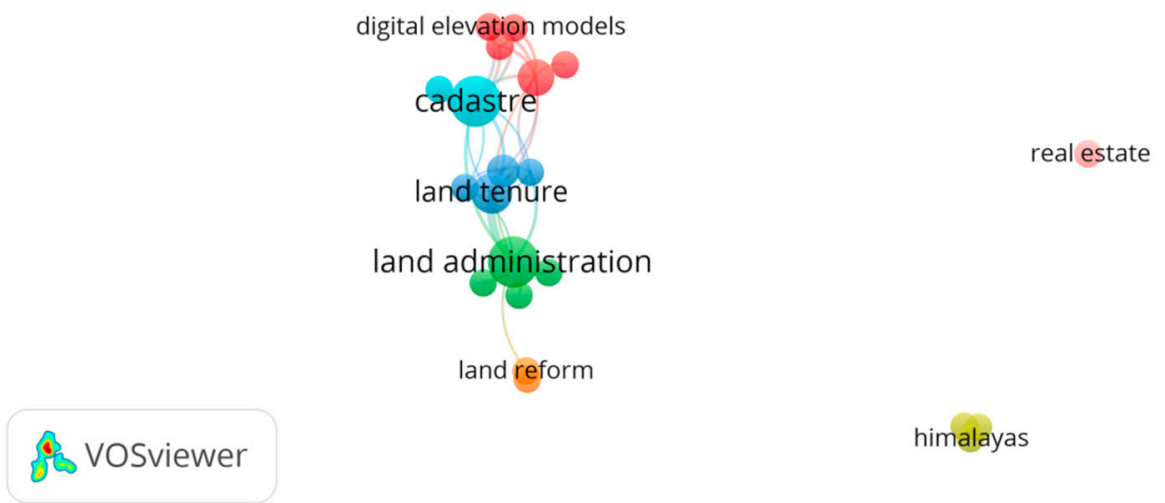

Figure 3. Keyword network map 1987-2001. 
* Regarding the color of the circle in VOS viewer, it is determined by the score of the item ranged from blue, green, to red. All label is visualized avoiding overlapping labels. It can be used different ways of coloring items to drop down the colors [41].

2002-2007: More keywords were observed in the keyword networks from this period than in those from the previous period (see Figure 4). The scope of the cadastre and land administration fields was extended through the incorporation of ICT terms (e.g., "digital data base," "3D cadastral data models," "cadastral data," and "digital cadastral map"). This implies that the cadastre approach that was developed in the 18th century was changing. In particular, during this period, the scope was actively extended to include the field of spatial information, and the "GIS" network was formed. Notably, this period launched cadastral template 2.0 in the annual meeting of FIG-commission, which was developed by research group for SDIs and land administration based on 17 data fields (see cadastral template 2.0 homepage).

Benhamu and Doytsher [73], and Stoter and van Oosterom [74] discussed 3D cadastres, in which the utilization of land registration and geodetic survey data in four dimensions are considered. It has been reported that this approach was used to extend the 2D cadastre of Israel to 3D.

Williamson [66] explained the history of the development of land administration and has predicted research methodologies, while other discussed the future of land administration centered on the value, use, and development of land ownership. In particular, the early 2010s can be regarded as a period in which information pertaining to cadastres and land was considered valuable to spatial data [75]. Thus, in 2005, land, real estate, and cadastral data provided the potential for smooth maintenance of complex controls over land, rights, limits, and obligations for the development of various government projects [76], such as planning and developing land and local operations [54,55], which are connected to core cadastral domain model (CCDM) [77] and e-LA [78]. During this period, the networks between the main keywords grew stronger than during the previous period (when the scope was extended). The development of cadastral research involved division into three fields: "cadastral map," "cadastral data," and "land administration." Above all, this period marked the emergence of "cadastral" and "land" as the central keywords; furthermore, networks formed with GIS were confirmed during this period.

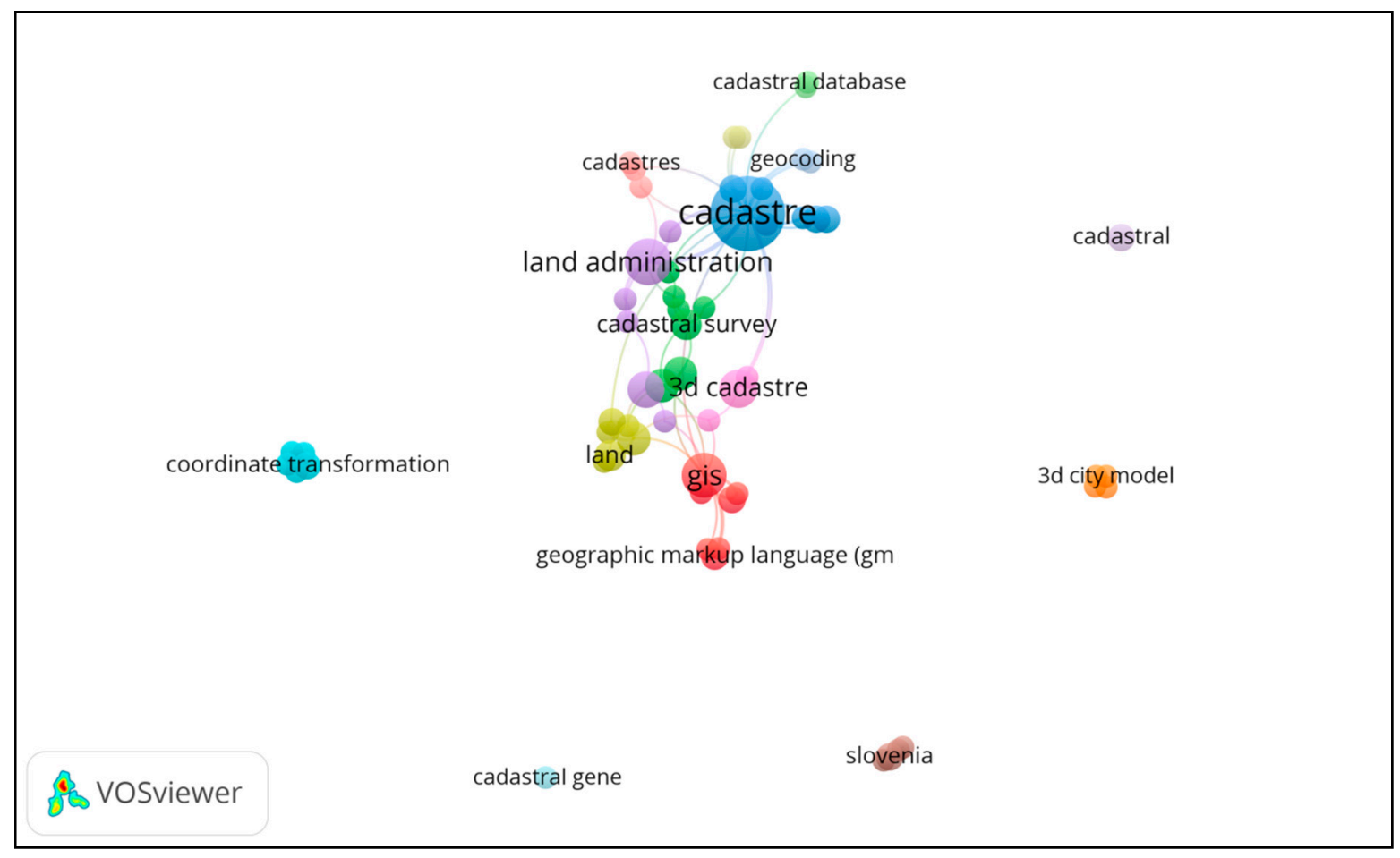

Figure 4. Keyword network map 2002-2007. 
2008-2014: During the most recent period, the overall shape of the keyword network changed. When compared with the previous keyword networks, the results showed that mainstream research subjects were being created and that keywords such as "cadastral," "cadastral map," "information system," "cadastral plan," and "land registration" were advancing as stronger core streams (see Figure 5).

In the late 2000s, cadastral data records were researched. The construction of metadata automation has allowed the metadata of spatial data to be updated automatically. This enables the user to build "information in hand" environment (that the user is comfortable with), overcoming the need to generate and update metadata [72]. As VGI [79] signifies voluntary participation in cartography, it is expensive and requires a large amount of effort (as for the production of earlier cadastral maps). This allowed people to get involved in cadastral surveys and producing cadastral maps using personal hand-held GPS equipment or satellite images. It allowed the collection of cadastral data using open-street maps and the collected data could now be utilized online through open platforms.

This study covered technical aspects using a 3D hybrid cadastre model [80], and the results showed that 2D cadastres changed to 3D cadastres owing to urbanization and the use of underground and above-ground spaces. This research proposed that effective 3D modeling should be carried out by incorporating spatial databases, 3D GIS, and computer-aided design (CAD). We proposed that $3 \mathrm{D}$ cadastre modeling should be performed by combining the existing 3D cadastre modeling methodologies. Advancements were made through the adoption of analysis methodologies, including the cadastral and spatial information fields that emerged at the beginning of 2000, which has enabled us to confirm the expansion of the knowledge network in the field of cadastral research.

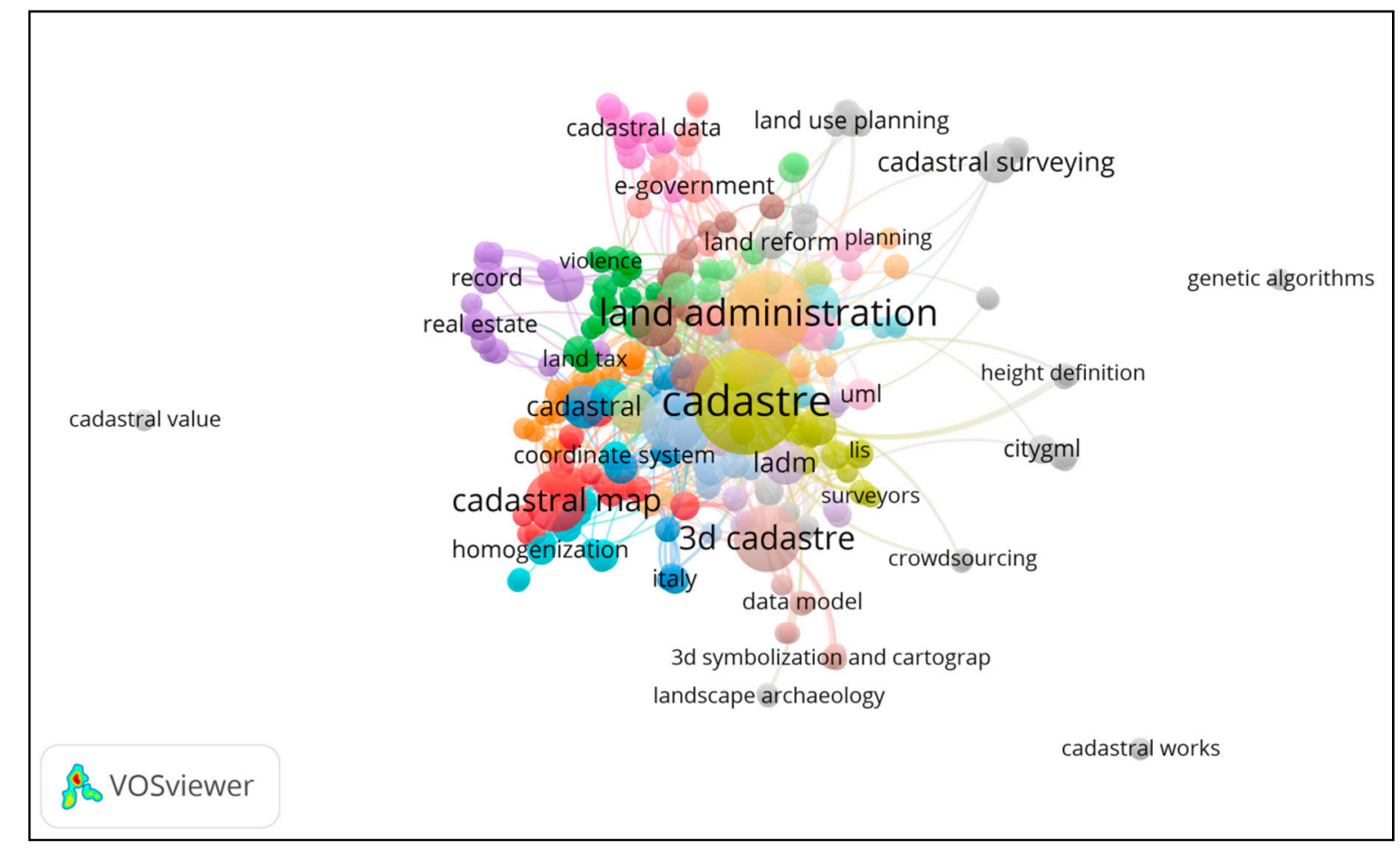

Figure 5. Keyword network map 2008-2014.

2015-2019: More keywords were observed in the keyword networks from this period than in those from the previous period. The scope of the cadastre and land administration fields was extended through the strengthening cadastral survey such as land cadastre, mapping, and real estate etc. Those trends show self-organization that was developed technology innovation in the land administration and cadaster (see Figure 6). 
Yang [81] investigated effective coordinate transformation on cadastral maps that utilized the World Geodetic System for the cadastral reform project. They proposed a method for providing clear and accurate cadastral maps through cadastral reform projects that corrected mapping errors. In a study on neo-cadastre [82], which represents another new trend in the cadastre field, VGI enabled individual citizens to make maps or write land tenures. The study used examples from three nations (Ghana, Canada, and Indonesia) to demonstrate the best method for considering land tenure rights that are based on the opinions of individuals and not on rules of laws from a national authority. Based on experiences from Latin America and Albania, it was suggested that accurate GPS and geodetic infrastructure should be built to develop the field of cadastral research in developing countries.

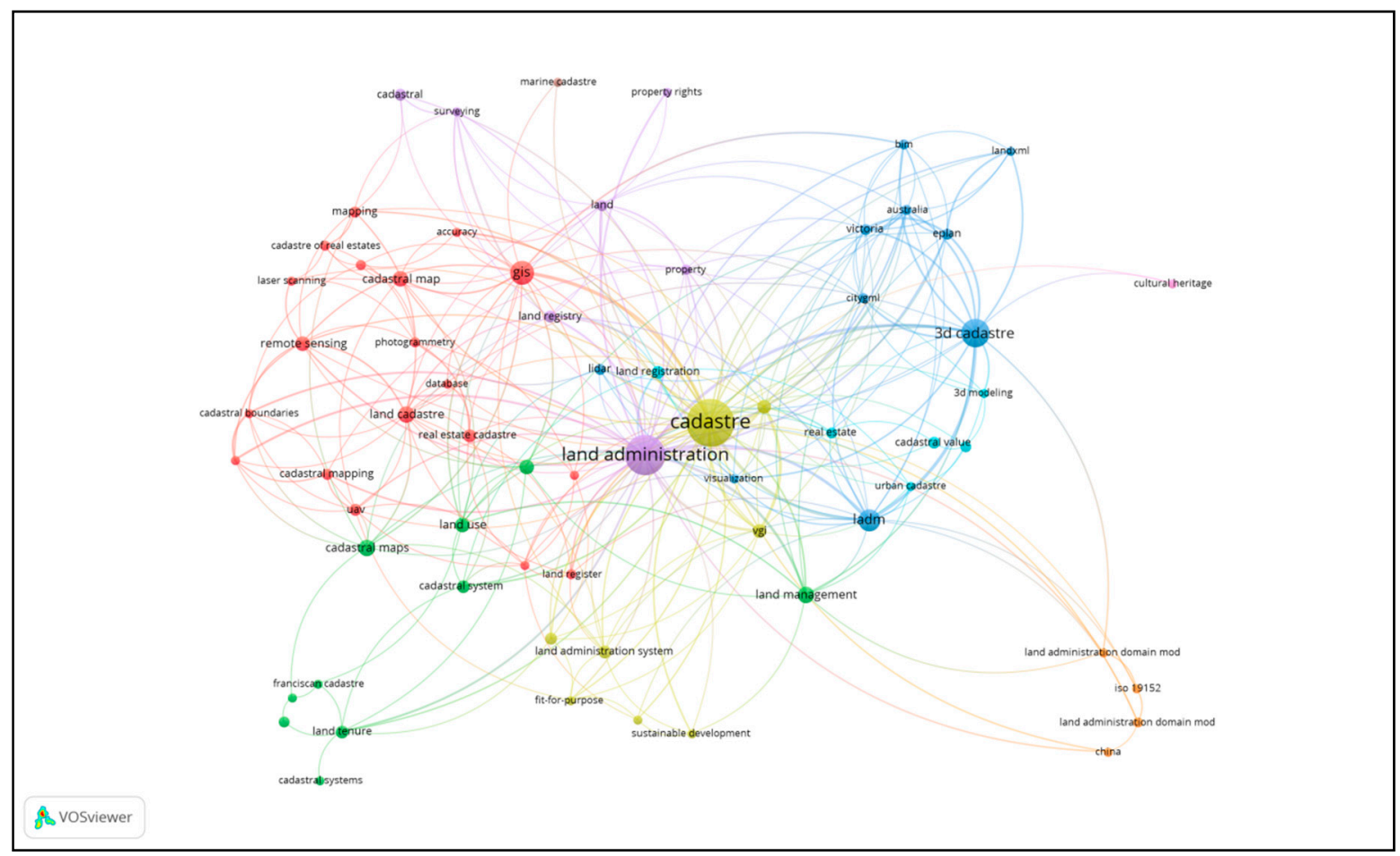

Figure 6. Keyword network map 2015-2019.

\subsection{Network Characteristics of Cadastral Research for Technology Innovation}

\subsubsection{Characteristics of Cluster Network}

Group analyses of data mining involves assigning objects to groups in which each object shares similar attributes [83]. In this study, group analyses by keyword's code were utilized to extract diverse features related to cadastres, and by utilizing the specific information for each group, this method allowed for the prediction of key research subjects in the field of cadastral research (see Figure 7).

The structural features of the network analyzed using the keywords extracted from the international academic papers published in the field of cadastral research from 1987 to 2019 were as follows: when keyword network was analyzed using the cluster network technique, five groups were formed. The keywords in each major group were as follows: GO covered issues relating to cadastres and real estate that contained the words "cadastre" and "cadastral map" G2 contained keywords relating to the legal system of cadastres, with primary keywords including "land register," "property right," and "land reform." G3 contained keywords concerned with "land registration," "cadastral system," "real estate by cadastral," and content related to land management where cadastre and ICT were combined. Those trends related to the direction of sustainable land use utilizing cadastres, and the keywords included "sustainable development," "coordinate system," and "ownership." G4 featured issues related to urban planning and the context of land management, with new keywords such as "land information system" 
and "real estate," etc., appearing in the works of Carmona et al. [84], Andrieu et al. [85], Smith et al. [86], and Gridan et al. [87]. The keywords in G5 were related to land use and the data generated during the digitalization of cadastre, such as "spatial data infrastructure" and "LADM (Land Administration Domain Model)," etc. As the groups include issues related to cadastres, by analyzing cluster networks, it is possible to utilize each group and highlight the overall evolution of the field of cadastral research.

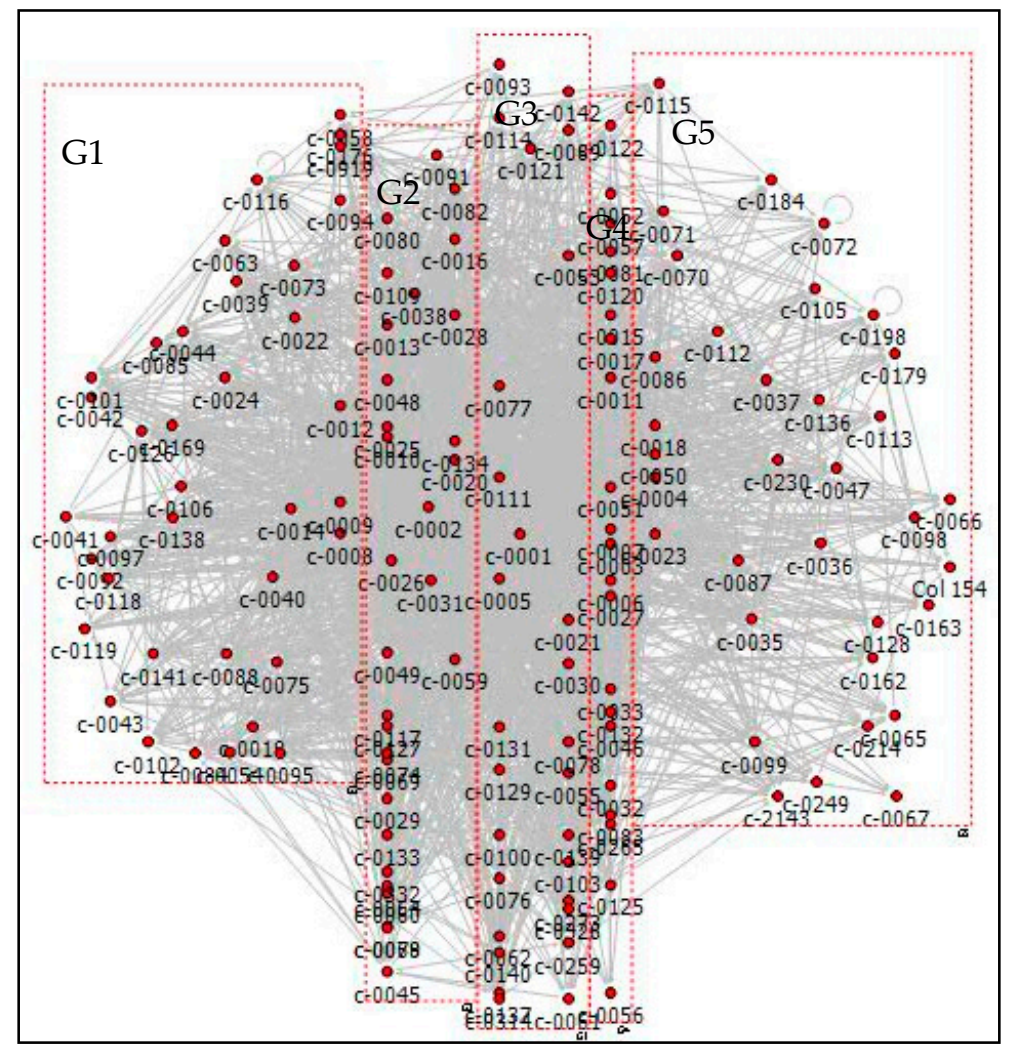

Figure 7. Cluster network structure of cadastral research.

\subsubsection{Network Structure Using the Centrality Index}

The keywords with a high centrality index included "property rights," "cadastral survey," "aerial photographs," and were related to "GIS," "LIS," and "spatial data," where cadastres and technology were combined. Furthermore, it was confirmed that keywords related to cadastral data and information had a high centrality index and could be considered the core keywords reflecting the latest research trends.

When we considered the upper-level nodes based on the nodes' betweenness centrality, we identified diverse keywords relating to new technologies in the fields of cadastral research and spatial information. High degrees of centrality index implied that the nodes were used with other keywords in papers, and the structure of the extended network for cadastral research was confirmed through the analysis of the results. GIS was found to belong to the same group of words as "land administration," "cadastral system," and "real estate," and showed high centrality for issues related to cadastres and real estate.

Closeness centrality represents the keyword at the center of the network, and researchers with an interest in the field of cadastral research can easily identify its evolution by carrying out a search for keywords with high closeness centrality. 


\subsubsection{Group Network and Group Density}

G2 and G5 formed a relatively large number of networks (564); this highlights the combination of new issues related to future continuous land use, such as the environment and landscape ecology. On the other hand, G3 and G4 showed a relatively small number of networks (199), implying that it is difficult to consider studies on the legal systems related to cadastres as new issues. The results confirmed that G2, G4, and G5 are the created legal systems in land use for urban planning (see Figure 8).

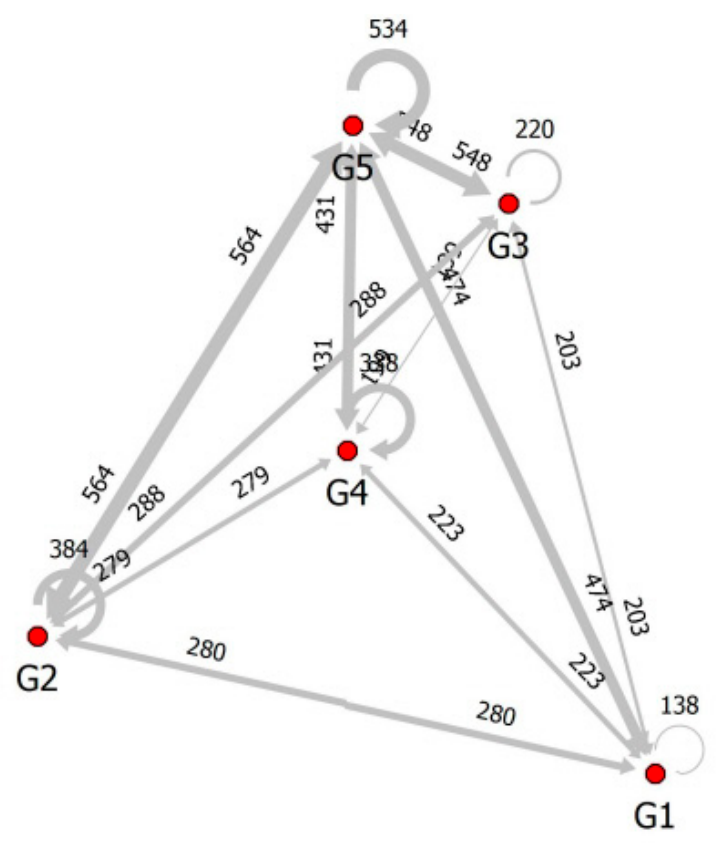

Figure 8. Group network-Two mode network.

The networks of each group obtained from cluster networks based on group density are shown using the spring-KK technique (Table 1). The indices of group density were as follows: the segregation matrix index (SMI), External-internal index (E-I), and cohesion indices were utilized for group analysis, and were used to compare grouped individual attribute units with other groups on the basis of network density, number of links, and degree of concentration. When we considered the density of each group in the analysis results, G5 had the highest density (showing a value of 0.619), followed by G2 and G3, which showed values of 0.54 and 0.529 , respectively. Among the cadastre studies, issues related to legal systems showed a high density; in particular, the results showed that legal system keywords were used in connection with the keywords of other groups.

Table 1. Group density.

\begin{tabular}{ccccc}
\hline & Density & E-I index & SMI & Cohesion Index \\
\hline G1 (real estate) & 0.324 & 0.755 & 0.015 & 0.629 \\
\hline G2 (legal system) & 0.54 & 0.66 & 0.145 & 0.644 \\
\hline G3 (land administration) & 0.529 & 0.668 & 0.306 & 0.824 \\
\hline G4 (urban planning) & 0.386 & 0.765 & 0.305 & 0.858 \\
\hline G5 (land use) & 0.619 & 0.663 & 0.144 & 0.713 \\
\hline
\end{tabular}

Issues related to cadastres and real estate also showed high densities, implying that there was a significant correlation between cadastre and real estate issues. The E-I index compares the number of internal links within a group with the number of external links shared with other groups; if the E-I 
index is 1, all the link nodes are from other groups. Accordingly, the fact that the E-I indices of G1, G3, and G4 were $0.755,0.668$, and 0.765 , respectively, showed that many link nodes of these groups were from other groups. This result showed that many issues related to continuous land use in the context of cadastres were linked with other groups; in particular, broad keywords were generated as academic synthesis resulted from the combination of cadastral and spatial information. The SMI index, which represents the degree of separation between groups, compares the density within a group and the link density between groups, with "other" meaning that groups are completely separated G3 also had a high cohesion index and density index, which showed that there is a close relationship between the keywords related to legal systems (e.g., cadastral law).

Group density can have a value between 0 and 1 . The E-I index is the calculated ratio between the numbers of external links to other groups and the internal links within a group. It varies between -1 and 1; the closer the value is to -1 , the greater the number of the internal links within a group; values closer to 1 indicate a greater number of external links with other groups. The SMI index is the ratio between the density of the external links to other groups and the density of the internal links within a group. It has a value between -1 and 1 . Unlike the E-I index, the closer the value is to -1 , the higher the density of the external links to other groups; the closer the value is to 1 , the higher the density of the internal links within a group. The cohesion index is the value obtained by dividing the density of the internal links within a group and the density of the external links to other groups. If the value is 1 , the density of internal links within a group is equal to the density of the external links to other groups; if the value is bigger than 1 , the density of links within a group is higher.

\section{Conclusions and Discussion}

\subsection{Conclusions}

This study analyzed the international cooperation trends and research subject patterns in the field of cadastral research for over 30 years (1987-2019). By considering cadastre-related papers on a year-by-year basis, we were able to observe the evolution of the cadastral research, along with that of the field of spatial information, which evolved to incorporate ICT. For example, academic papers in the field of cadastral research showed a steady evolution up to 2005; however, a rapidly increasing trend after 2005. This study not only combined the research methods of semantic analysis and keyword network, but also determined the characteristics of each group, analyzed the group networks, and extracted the centrality and density indices. This analysis has provided objective and qualitative evidence for the process of evolution in the field of cadastral research.

To summarize the progress of cadastral research, we found that there were common parameters, such as property rights, spatial data infrastructure, LADM, etc. Maintenance of these parameters has come to the fore, with increase in interest in the development of open data. Methods that handle cadastral research are changing rapidly with the development of technologies (such as photogrammetric, remote sensing, 3D, etc.). We predict that henceforth, various methods that handle the new aerial and marine surveying techniques will be incorporated into cadastral surveying. We found that the essence of cadastral research has not changed over time but, as with many other fields, the methods have diversified. The evolution process before 2001, studies on cadastres were generally characterized by content related to analog cadastres. After 2000, the field evolved from paper-based land administration system (LAS) to online LAS through the use of the internet. Results showed that from 2000, through the advancement of the internet, the field of cadastral administration advanced by merging with online LAS, and the research field related to the integration of SES steadily developed. Furthermore, studies of legal systems were carried out after 2005 to reduce land disputes through the revision of cadastral maps. Our research intended to provide empirical evidence that the progress of this field involved combining cadastral and spatial information based on land administration systems for sustainable development [88-90]. However, by performing a keyword network analysis, this study quantitatively proved that cadastres and spatial information are evolving. These keywords reflect the critical role 
of SES in cadastral surveys. Interestingly, SES received more attention in these early years. This was probably due to the good land governance of land administrations, which was integrated with global agendas and looked to achieve sustainable development [91].

Regarding the legal systems, the field of cadastral research is closely related to "ownership," which implies that the issues related to legal issues of cadastres should be included through synthesis with other fields, rather than formation of stand-alone issues. Accordingly, this field require to incorporate the diversity of related studies through academic synthesis with other fields.

\subsection{Discussion}

The results showed the advancement of technology innovation in cadastres, as highlighted in the combination of the relevant keywords majorly from those related with spatial information technology and citizen's participation. This trend confirmed that open data have emerged as new issues as spatial data utilization. These issues are combined with solving social issues, such as crime prevention and management vacant house. Thus, in time, standardization of spatial data cadastral research will be challenging; these new issues are expected to drive the evolution of the academic scope in the future through synthesis with other fields.

One characteristic that has recently become prominent in the evolution of research on cadastres is that cadastre-related services standardized by the use of smart technology have been promoted. This is related to the advancing policies of different countries, including open data, although policies face some limitations depending on each country's conditions for land administration.

Another phenomenon is the direct participation of civilians in producing cadastral maps, as in VGI. Cadastral work is shifting from a government-led, top-down field with passive participation into a field involving voluntary civilian participation. The roles of land administration are evolving into a system that maintains new 3D and 4D registration matter above and below the subject land, along with systems in which real-time updates are possible. In the future, a legal basis must be established to enable changes that will allow for an environment where the registration maintenance of rights that account for environmental changes can be updated in real time. The role of cadastres in providing legal bases for land ownership rights and land readjustments must continue. However, methods that deal with cadastres must also be continuously updated for smart land management policy.

Through semantic analysis, previously unknown information can be obtained by extracting valuable data from extensive data pools. Although diverse information about studies in the field of cadastral research can be obtained using various techniques, it is unclear how these data can predict which future technologies will facilitate the advancement of cadastral research.

Conflicts of Interest: The authors declare no conflict of interest.

\section{Appendix A}

SMI, E-I, and cohesion index are used for group density analysis, that compares with other group by link, density and cohesion in network. The mean of SMI (segregation matrix index) created by Fershtman and Chen. SMI $=\left(\mathrm{d} \_\mathrm{AA}-\mathrm{d} \_\mathrm{AB}\right) /\left(\mathrm{d} \_\mathrm{AA}+\mathrm{d} \_\mathrm{BB}\right)$, where $\mathrm{d} \_\mathrm{XY}$ means density of choices from $X$ to $Y$. If group A segregates (reveals self-preference), $\mathrm{SMI}>0$. In the extreme case where A segregates completely, its members direct no choice outward, $\mathrm{SMI}=1$. In contrast, where A's members reveal other-preference, it will direct all their choices outwards, SMI $=-1$. Density described giving densities for each group. E-I index compares the number of links between actors of the same type and between actors of different type. The index ranges between -1 and $1,-1$ indicating that all ties connect nodes of the same type and vice versa. Cohesion index described the extent to which ties are concentrated within a subgroup, rather than between subgroup (see Tables A1 and A2).

Node-betweeness centrality: This measured by the extent to which a node lies between all other pair of nodes on the geodesic path. They behave in a similar way to "broker" by bridging between nodes. 
Closeness centrality: This module analyzes centrality of a network structure based on geodesic distances among the nodes. centrality is measured by the inverse of the sum of distances from a node to all the other nodes, which is then normalized by multiplying it by (n-1)(Netminer manual).

Table A1. Major issues in cadastral research by Group.

\begin{tabular}{|c|c|c|c|c|c|c|c|c|c|c|c|c|c|c|}
\hline \multicolumn{3}{|c|}{ G1 (real estate) } & \multicolumn{3}{|c|}{ G2 (legal system) } & \multicolumn{3}{|c|}{ G3 (land administration) } & \multicolumn{3}{|c|}{ G4 (urban planning) } & \multicolumn{3}{|c|}{ G5 (land use) } \\
\hline Keywords & Code & $\mathbf{N}$ & Keywords & Code & $\mathbf{N}$ & Keywords & Code & $\mathbf{N}$ & Keywords & Code & $\mathbf{N}$ & Keywords & Code & $\mathbf{N}$ \\
\hline Cadastre & c-0001 & 136 & cadastral & c-0008 & 15 & $\begin{array}{l}\text { Land } \\
\text { administration }\end{array}$ & $c-0002$ & 80 & $\begin{array}{c}\text { 3D } \\
\text { cadastre }\end{array}$ & c-0003 & 39 & GIS & c-0004 & 38 \\
\hline $\begin{array}{l}\text { Cadastral } \\
\text { map }\end{array}$ & c-0005 & 32 & $\begin{array}{l}\text { Cadastral } \\
\text { survey }\end{array}$ & c-0009 & 15 & $\begin{array}{l}\text { Land } \\
\text { registration }\end{array}$ & c-0010 & 15 & $\begin{array}{l}\text { Cadastral } \\
\text { maps }\end{array}$ & c-0006 & 19 & Land use & c-0018 & 10 \\
\hline $\begin{array}{l}\text { Stable } \\
\text { cadastre }\end{array}$ & c-0021 & 9 & $\begin{array}{l}\text { Land } \\
\text { tenure }\end{array}$ & c-0012 & 13 & $\begin{array}{l}\text { Land } \\
\text { registry }\end{array}$ & c-0013 & 12 & $\begin{array}{c}\text { Land } \\
\text { cadastre }\end{array}$ & c-0007 & 18 & land & c-0023 & 8 \\
\hline $\begin{array}{l}\text { Administ } \\
\text { ration }\end{array}$ & c-0030 & 6 & $\begin{array}{l}\text { Property } \\
\text { rights }\end{array}$ & c-0014 & 11 & $\begin{array}{l}\text { Cadastral } \\
\text { system }\end{array}$ & c-0016 & 10 & Cadastre & c-0011 & 13 & $\begin{array}{l}\text { Land } \\
\text { adminis } \\
\text { tration } \\
\text { system }\end{array}$ & c-0035 & 6 \\
\hline Property & c-0077 & 4 & $\begin{array}{l}\text { Land } \\
\text { reform }\end{array}$ & c-0019 & 9 & $\begin{array}{c}\text { Real estate } \\
\text { cadastre }\end{array}$ & c-0020 & 9 & $\begin{array}{l}\text { Cadastral } \\
\text { surveying }\end{array}$ & c-0015 & 10 & $\begin{array}{l}\text { Marine } \\
\text { cadastre }\end{array}$ & c-0037 & 6 \\
\hline $\begin{array}{l}\text { Coordinate } \\
\text { transfor } \\
\text { mation }\end{array}$ & c-0061 & 4 & $\begin{array}{l}\text { Cadastral } \\
\text { data }\end{array}$ & c-0022 & 8 & LADM & c-0026 & 7 & GPS & c-0017 & 10 & $\begin{array}{l}\text { Land } \\
\text { adminis } \\
\text { tration } \\
\text { systems }\end{array}$ & $c-0036$ & 6 \\
\hline $\begin{array}{c}3 \mathrm{D} \\
\text { property }\end{array}$ & c-0053 & 4 & $\begin{array}{l}\text { Land } \\
\text { register }\end{array}$ & c-0024 & 8 & accuracy & c-0025 & 7 & $\begin{array}{c}\text { Real } \\
\text { estate }\end{array}$ & c-0027 & 7 & $\begin{array}{l}\text { Land use } \\
\text { planning }\end{array}$ & c-0047 & 5 \\
\hline $\begin{array}{l}\text { Building } \\
\text { cadastre }\end{array}$ & c-0055 & 4 & Turkey & c-0039 & 6 & $\begin{array}{l}\text { Sustainable } \\
\text { development }\end{array}$ & c-0028 & 7 & Datab\#ase & c-0033 & 6 & $\begin{array}{l}\text { Spatial } \\
\text { data } \\
\text { infrastructure }\end{array}$ & c-0050 & 5 \\
\hline $\begin{array}{l}\text { Data } \\
\text { model }\end{array}$ & c-0062 & 4 & $\begin{array}{l}\text { Cadastral } \\
\text { database }\end{array}$ & c-0040 & 5 & uml & c-0029 & 7 & $\begin{array}{c}\text { Cultural } \\
\text { landscape }\end{array}$ & c-0032 & 6 & Housing & $c-0065$ & 4 \\
\hline $\begin{array}{l}\text { Photogra } \\
\text { mmetry }\end{array}$ & c-0076 & 4 & $\begin{array}{c}\text { Cadastral } \\
\text { parcel }\end{array}$ & c-0044 & 5 & Record & c-0038 & 6 & Topology & c-0051 & 5 & Italy & c-0066 & 4 \\
\hline $\begin{array}{l}\text { Public } \\
\text { good }\end{array}$ & c-0078 & 4 & $\begin{array}{l}\text { Cadastral } \\
\text { information } \\
\text { system }\end{array}$ & c-0041 & 5 & $\begin{array}{c}\text { Aerial } \\
\text { photographs }\end{array}$ & c-0031 & 6 & $\begin{array}{l}\text { Urban } \\
\text { planning }\end{array}$ & c-0052 & 5 & $\begin{array}{l}\text { Land } \\
\text { markets }\end{array}$ & c-0070 & 4 \\
\hline \multirow[t]{8}{*}{$\begin{array}{l}\text { Utility } \\
\text { cadastre }\end{array}$} & c-0089 & 4 & $\begin{array}{c}\text { Cadastral } \\
\text { manage } \\
\text { ment }\end{array}$ & c-0042 & 5 & Cartography & c-0045 & 5 & $\begin{array}{l}\text { Land } \\
\text { information } \\
\text { system }\end{array}$ & c-0046 & 5 & $\begin{array}{l}\text { Land } \\
\text { rights }\end{array}$ & c-0072 & 4 \\
\hline & & & $\begin{array}{l}\text { Cadastral } \\
\text { mapping }\end{array}$ & c-0043 & 5 & Ownership & c-0048 & 5 & $\begin{array}{c}\text { Cadastral } \\
\text { measure } \\
\text { ments }\end{array}$ & c-0057 & 4 & $\begin{array}{l}\text { Spatial } \\
\text { data }\end{array}$ & c-0086 & 4 \\
\hline & & & $\begin{array}{l}\text { Geographic } \\
\text { information } \\
\text { system }\end{array}$ & c-0063 & 4 & Parcel & c-0049 & 5 & $\begin{array}{l}\text { Cadastral } \\
\text { gene }\end{array}$ & c-0056 & 4 & $\begin{array}{l}\text { Standar } \\
\text { dization }\end{array}$ & c-0087 & 4 \\
\hline & & & $\begin{array}{c}\text { Cadastral } \\
\text { resurvey } \\
\text { project }\end{array}$ & c-0058 & 4 & $\begin{array}{l}\text { Land } \\
\text { management }\end{array}$ & c-0069 & 4 & $\begin{array}{l}\text { Reeng } \\
\text { ineering }\end{array}$ & c-0081 & 4 & $\begin{array}{l}\text { Land } \\
\text { adminis } \\
\text { tration } \\
\text { domain } \\
\text { model } \\
\text { (ladm) }\end{array}$ & c-0067 & 4 \\
\hline & & & Management & ttc-0075 & 4 & Cadastres & c-0059 & 4 & $\begin{array}{l}\text { Remote } \\
\text { sensing }\end{array}$ & c-0083 & 4 & $\begin{array}{l}\text { Land } \\
\text { parcel }\end{array}$ & c-0071 & 4 \\
\hline & & & Surveying & c-0088 & 4 & $\begin{array}{c}\text { Coordinate } \\
\text { system }\end{array}$ & c-0060 & 4 & & & & & & \\
\hline & & & Australia & c-0054 & 4 & $\begin{array}{l}\text { Homoge } \\
\text { nization }\end{array}$ & c-0064 & 4 & & & & & & \\
\hline & & & $\begin{array}{l}\text { Landscape } \\
\text { change }\end{array}$ & c-0073 & 4 & $\begin{array}{l}\text { Land } \\
\text { consolidation }\end{array}$ & c-0068 & 4 & & & & & & \\
\hline
\end{tabular}


Table A1. Cont.

\begin{tabular}{|c|c|c|c|c|c|c|c|c|c|c|c|c|c|c|}
\hline \multicolumn{3}{|c|}{ G1 (real estate) } & \multicolumn{3}{|c|}{ G2 (legal system) } & \multicolumn{3}{|c|}{ G3 (land administration) } & \multicolumn{3}{|c|}{ G4 (urban planning) } & \multicolumn{3}{|c|}{ G5 (land use) } \\
\hline Keywords & Code & $\mathbf{N}$ & Keywords & Code & $\mathbf{N}$ & Keywords & Code & $\mathbf{N}$ & Keywords & Code & $\mathbf{N}$ & Keywords & Code & $\mathbf{N}$ \\
\hline & & & $\begin{array}{c}\text { Rural } \\
\text { landscape }\end{array}$ & c-0084 & 4 & Land tax & c- 0074 & 4 & & & & & & \\
\hline & & & Slovenia & c-0085 & 4 & $\begin{array}{c}\text { Real } \\
\text { property }\end{array}$ & c-0080 & 4 & & & & & & \\
\hline & & & & & & Registration & c-0082 & 4 & & & & & & \\
\hline & & & & & & $\begin{array}{l}\text { Real estate } \\
\text { property }\end{array}$ & c-0079 & 4 & & & & & & \\
\hline
\end{tabular}

* The name of each group indicates representative issues.

Table A2. Centrality index in the keyword network.

\begin{tabular}{|c|c|c|c|c|c|c|c|c|}
\hline Keywords & Code & Group & Num. & $\begin{array}{l}\text { In-Degree } \\
\text { Centrality }\end{array}$ & Rank & $\begin{array}{l}\text { In-Close } \\
\text { ness }\end{array}$ & $\begin{array}{c}\text { Node } \\
\text { Betweenness } \\
\text { Centrality }\end{array}$ & $\begin{array}{c}\text { Eigenvector } \\
\text { Centrality }\end{array}$ \\
\hline $\begin{array}{l}\text { Property } \\
\text { rights }\end{array}$ & c-0014 & G2 & 11 & 10.28859 & 1 & 0.873656 & 0.061366 & 0.480301 \\
\hline $\begin{array}{l}\text { Cadastral } \\
\text { survey }\end{array}$ & c-0009 & G2 & 15 & 4.47651 & 2 & 0.767338 & 0.065728 & 0.203429 \\
\hline $\begin{array}{c}\text { Aerial } \\
\text { photographs }\end{array}$ & c-0031 & G3 & 6 & 3.738255 & 3 & 0.700613 & 0.020025 & 0.179902 \\
\hline GIS & c-0004 & G5 & 38 & 3.369128 & 4 & 0.662223 & 0.105017 & 0.257324 \\
\hline $\begin{array}{c}\text { Land } \\
\text { administration }\end{array}$ & c-0002 & G3 & 80 & 3.208054 & 5 & 0.763299 & 0.203193 & 0.370056 \\
\hline 3D cadastre & c-0003 & G4 & 39 & 1.57047 & 6 & 0.622433 & 0.037929 & 0.119734 \\
\hline $\begin{array}{l}\text { Cadastral } \\
\text { maps }\end{array}$ & c-0006 & G4 & 19 & 1.328859 & 7 & 0.584786 & 0.027394 & 0.107867 \\
\hline $\begin{array}{l}\text { Spatial data } \\
\text { infrastructure }\end{array}$ & c-0050 & G5 & 5 & 1.201342 & 8 & 0.599284 & 0.017262 & 0.071226 \\
\hline $\begin{array}{l}\text { Land } \\
\text { registration }\end{array}$ & c-0010 & G3 & 15 & 0.979866 & 9 & 0.519809 & 0.009563 & 0.128593 \\
\hline Record & c-0038 & G3 & 6 & 0.979866 & 10 & 0.559949 & 0.004723 & 0.073295 \\
\hline LADM & c-0026 & G3 & 7 & 0.959732 & 11 & 0.56212 & 0.016535 & 0.075544 \\
\hline Real estate & c-0027 & G4 & 7 & 0.912752 & 12 & 0.564307 & 0.042504 & 0.099772 \\
\hline $\begin{array}{l}\text { Land } \\
\text { registry }\end{array}$ & c-0013 & G3 & 12 & 0.744966 & 13 & 0.529295 & 0.009868 & 0.066123 \\
\hline $\begin{array}{l}\text { Land } \\
\text { cadastre }\end{array}$ & c-0007 & G4 & 18 & 0.724832 & 14 & 0.537136 & 0.015275 & 0.101859 \\
\hline Cadastral & c-0008 & G2 & 15 & 0.711409 & 15 & 0.547271 & 0.087137 & 0.245886 \\
\hline Governance & c-0111 & G1 & 3 & 0.691275 & 16 & 0.573229 & 0.009751 & 0.03124 \\
\hline $\begin{array}{l}\text { Cadastral } \\
\text { map }\end{array}$ & c-0005 & G1 & 32 & 0.684564 & 17 & 0.545214 & 0.02987 & 0.115427 \\
\hline $\begin{array}{l}\text { Real estate } \\
\text { cadastre }\end{array}$ & c-0020 & G3 & 9 & 0.604027 & 18 & 0.529295 & 0.006791 & 0.052356 \\
\hline Standardization & c-0087 & G5 & 4 & 0.597315 & 19 & 0.541145 & 0.005873 & 0.02907 \\
\hline GPS & c-0017 & G4 & 10 & 0.503356 & 20 & 0.531234 & 0.004141 & 0.036368 \\
\hline $\begin{array}{l}\text { Marine } \\
\text { cadastre }\end{array}$ & c-0037 & G5 & 6 & 0.503356 & 21 & 0.533187 & 0.001397 & 0.033155 \\
\hline
\end{tabular}


Table A2. Cont.

\begin{tabular}{|c|c|c|c|c|c|c|c|c|}
\hline Keywords & Code & Group & Num. & $\begin{array}{l}\text { In-Degree } \\
\text { Centrality }\end{array}$ & Rank & $\begin{array}{l}\text { In-Close } \\
\text { ness }\end{array}$ & $\begin{array}{c}\text { Node } \\
\text { Betweenness } \\
\text { Centrality }\end{array}$ & $\begin{array}{c}\text { Eigenvector } \\
\text { Centrality }\end{array}$ \\
\hline $\begin{array}{c}\text { Cadastral } \\
\text { data }\end{array}$ & c-0022 & G2 & 8 & 0.463087 & 22 & 0.529295 & 0.006733 & 0.040941 \\
\hline $\begin{array}{c}\text { Stable } \\
\text { cadastre }\end{array}$ & c-0021 & G1 & 9 & 0.42953 & 23 & 0.521679 & 0.004719 & 0.035984 \\
\hline Land use & c-0018 & G5 & 10 & 0.416107 & 24 & 0.523563 & 0.016884 & 0.097905 \\
\hline $\begin{array}{l}\text { Multipurpose } \\
\text { cadastre }\end{array}$ & c-0127 & G3 & 3 & 0.416107 & 25 & 0.51428 & 0.001374 & 0.028968 \\
\hline Cadastre & c-0011 & G4 & 13 & 0.409396 & 26 & 0.52737 & 0.004459 & 0.032614 \\
\hline $\begin{array}{l}\text { Cadastral } \\
\text { database }\end{array}$ & c-0040 & G2 & 5 & 0.369128 & 27 & 0.51428 & 0.003961 & 0.025503 \\
\hline $\begin{array}{l}\text { DAZD (State } \\
\text { archive in } \\
\text { Zadar) }\end{array}$ & c-0136 & G5 & 3 & 0.369128 & 28 & 0.507087 & 0.001656 & 0.01806 \\
\hline Land register & c-0024 & G2 & 8 & 0.33557 & 29 & 0.480221 & 0.003747 & 0.041502 \\
\hline Surveying & c-0088 & G2 & 4 & 0.33557 & 30 & 0.52737 & 0.005663 & 0.031123 \\
\hline
\end{tabular}

\section{References}

1. Billen, R.; Zlatanova, S. 3D spatial relationships model: A useful concept for 3D cadastre? Comput. Environ. Urban Syst. 2003, 27, 411-425. [CrossRef]

2. Shojaei, D.; KalantariIan, M.; Bishop, I.D.; Rajabifard, A.; Aien, A. Visualization requirements for 3D cadastral systems. Comput. Environ. Urban Syst. 2013, 41, 39-54. [CrossRef]

3. Aien, A.; Kalantari, M.; Rajabifard, A.; Williamson, I.; Wallace, J. Towards integration of 3D legal and physical objects in cadastral data models. Land Use Policy 2013, 35, 140-154. [CrossRef]

4. Stoter, J.E.; van Oosterom, P. Technological aspects of a full 3D cadastral registration. Int. J. Geogr. Inf. Sci. 2005, 19, 669-696. [CrossRef]

5. Stoter, J.; Salzmann, M. Towards a 3D cadastre: Where do cadastral needs and technical possibilities meet? Comput. Environ. Urban Syst. 2003, 27, 395-410. [CrossRef]

6. Selleri, M.; Fabrizi, C. The role of ICT in the devolution of cadastral service. In Proceedings of the FIG 2003 Strategies for Renewal of Information Systems and Information Technology for Land Registry and Cadastre, Symposium held by the FIG Commission, Enschede, The Netherlands, 8-9 May 2003.

7. van Oosterom, P.; Lemmen, C.; De By, R.; Tuladar, A. Geo-ICT technology push vs. cadastral market pull. In Proceedings of the OEEPE Workshop on the Next Generation Spatial Databases, Southampton, UK, 22-24 May 2002.

8. Silva, M.A.; Stubkjær, E. A review of methodologies used in research on cadastral development. Comput. Environ. Urban Syst. 2002, 26, 403-423. [CrossRef]

9. Bender, O.; Boehmer, H.J.; Jens, D.; Schumacher, K.P. Analysis of land-use change in a sector of Upper Franconia (Bavaria, Germany) since 1850 using land register records. Landsc. Ecol. 2005, 20, 149-163. [CrossRef]

10. Skånes, H.M.; Bunce, R.G.H. Directions of landscape change (1741-1993) in Virestad, Sweden-Characterised by multivariate analysis. Landsc. Urban Plan. 1997, 38, 61-75. [CrossRef]

11. Van Oosterom, P.; Lemmen, C.; Ingvarsson, T.; van der Molen, P.; Ploeger, H.; Quak, W.; Stoter, J.; Zevenbergen, J. The core cadastral domain model. Comput. Environ. Urban Syst. 2006, 30, 627-660. [CrossRef]

12. Navratil, G.; Frank, A.U. Processes in a cadastre. Comput. Environ. Urban Syst. 2004, 28, 471-486. [CrossRef]

13. Olfat, H.; Shojaei, D.; Briffa, M.; Maley, S.; Rajabifard, A. Strategic actions for increasing the submission of digital cadastral data by the surveying industry based on lessons learned from Victoria, Australia. ISPRS Int. J. Geo Inf. 2018, 7, 47. [CrossRef]

14. Van Oosterom, P. Research and development in 3D cadastres. Comput. Environ. Urban Syst. 2013, 40, 1-6. [CrossRef] 
15. Williamson, I.P. The evolution of modern cadastres. In Proceedings of the New Technology for a New Century Conference, FWW2001, Seoul, Korea, 8 May 2001.

16. Assefa, S.G.; Rorissa, A. A bibliometric mapping of the structure of STEM education using co-word analysis. J. Am. Soc. Inf. Sci. Technol. 2013, 64, 2513-2536. [CrossRef]

17. Abejón, R.; Pérez-Acebo, H.; Garea, A. A bibliometric analysis of research on supported ionic liquid membranes during the 1995-2015 period: Study of the main applications and trending topics (Open Access). Membranes 2017, 7, 63. [CrossRef] [PubMed]

18. Aleixandre-Benavent, R.; Aleixandre-Tudó, J.L.; Castelló-Cogollos, L.; Aleixandre, J.L. Trends in global research in deforestation. A bibliometric analysis. Land Use Policy 2018, 72, 293-302. [CrossRef]

19. Bielecka, E.; Burek, E. Spatial data quality and uncertainty publication patterns and trends by bibliometric analysis (Open Access). Open Geosci. 2019, 11, 219-235. [CrossRef]

20. Chen, Q.; Geng, N.; Zhu, K. Review and bibliometric analysis of Chinese agricultural economics research: 2006-2015. China Agric. Econ. Rev. 2018, 10, 152-172. [CrossRef]

21. Chiu, W.-T.; Ho, Y.-S. Bibliometric analysis of homeopathy research during the period of 1991 to 2003. Scientometrics 2005, 63, 3-23. [CrossRef]

22. Goyal, N. A "review" of policy sciences: Bibliometric analysis of authors, references, and topics during 1970-2017. Policy Sci. 2017, 50, 527-537. [CrossRef]

23. Güzeller, C.O.; Çeliker, N. Gastronomy from past to today: A bibliometrical analysis. J. Tour. Gastr. Stud. 2017, 5, 88-102. [CrossRef]

24. Hood, W.W.; Wilson, C.S. The literature of bibliometrics, scientometrics, and informetrics. Scientometrics 2001, 52, 291-314. [CrossRef]

25. Kasemodel, M.C.; Makishi, F.; Souza, R.C.; Silva, V.-L. Following the trail of crumbs: A bibliometric study on consumer behavior in the Food Science and Technology field (Open Access). Int. J. Food Stud. 2016, 5, 73-83. [CrossRef]

26. Li, N.; Han, R.; Lu, X. Bibliometric analysis of research trends on solid waste reuse and recycling during 1992-2016. Resour. Conserv. Recyl. 2018, 130, 109-117. [CrossRef]

27. Liu, F.; Lin, A.; Wang, H.; Peng, Y.; Hong, S. Global research trends of geographical information system from 1961 to 2010: A bibliometric analysis. Scientometrics 2016, 106, 751-768. [CrossRef]

28. Ye, Z.; Zhang, B.; Liu, Y.; Zhang, J.; Wang, Z.; Bi, H. A bibliometric investigation of research trends on sulfate removal. Desalin. Water Treat. 2014, 52, 6040-6049. [CrossRef]

29. Polat, Z.A. Evolution and future trends in global research on cadastre: A bibliometric analysis. GeoJournal 2019, 84, 1121-1134. [CrossRef]

30. Zhang, H.; Huang, M.; Qing, X.; Li, G.; Tian, C. Bibliometric analysis of global remote sensing research during 2010-2015 (Open Access). ISPRS Int. J. Geo Inf. 2017, 6, 332. [CrossRef]

31. Niu, J.; Tang, W.; Xu, F.; Zhou, X.; Song, Y. Global research on artificial intelligence from 1990-2014: Spatially-explicit bibliometric analysis (Open Access). ISPRS Int. J. Geo Inf. 2016, 5, 66. [CrossRef]

32. Tian, Y.; Wen, C.; Hong, S. Global scientific production on GIS research by bibliometric analysis from 1997 to 2006. J. Informetr. 2008, 2, 65-74. [CrossRef]

33. Ackerly, D.D.; Loarie, S.R.; Cornwell, W.K.; Weiss, S.B.; Hamilton, H.; Branciforte, R.; Kraft, N.J.B. The geography of climate change: Implications for conservation biogeography. Divers. Distrib. 2010, 16, 476-487. [CrossRef]

34. E Fonseca, B.P.F.; Sampaio, R.B.; Fonseca, M.V.A.; Zicker, F. Co-authorship network analysis in health research: Method and potential use (Open Access). Health Res. Policy Syst. 2016, 14, 34. [CrossRef] [PubMed]

35. Nepal, S.K. Traditions and trends: A review of geographical scholarship in tourism. Tour. Geogr. 2009, 11, 2-22. [CrossRef]

36. Zevenbergen, J. A systems approach to land registration and Cadastre. Nord. J. Surv. Real Estate Res. 2004, 1, $11-24$.

37. Nohria, N.; Eccles, R.G. School, Networks and Organizations: Structure, Form, and Action; Harvard Business School Press: Boston, MA, USA, 1992.

38. Wasserman, S.; Galaskiewicz, J. Advances in Social Network Analysis: Research in the Social and Behavioral Sciences; Sage Publications Inc.: Thousand Oaks, CA, USA, 1994.

39. Wellman, B.; Berkowitz, S.D. Introduction: Studying social structures. In Social Structures: A Network Approach; Cambridge University Press: Cambridge, MA, USA, 1988; pp. 1-14. 
40. Su, H.-N.; Lee, P.C. Network perspective of science and technology policy research community in Taiwan. In Proceedings of the Technology Management for Global Economic Growth (PICMET), Phuket, Thailand, 18-22 July 2010.

41. Van Eck, N.J.; Waltman, L. 2013 VOS Viewer Manual, Manual for VOS Viewer Version 1.5.4. Available online: http://www.vosviewer.com/documentation/Manual_VOSviewer_1.5.4.pdf (accessed on 1 December 2019).

42. Cho, I.; Kim, N. Recommending core and connecting keywords of research area using social network and data mining techniques. J. Intell. Inf. Syst. 2011, 17, 127-138.

43. Coulter, N.; Monarch, I.; Konda, S. Software engineering as seen through its research literature: A study in co-word analysis. J. Am. Soc. Inf. Sci. 1998, 49, 1206-1223. [CrossRef]

44. Callon, M.; Courtial, J.P.; Laville, F. Co-word analysis as a tool for describing the network of interactions between basic and technological research: The case of polymer chemistry. Scientometrics 1991, 22, 155-205. [CrossRef]

45. Ho, Y.-S. Bibliometric analysis of adsorption technology in environmental science. J. Environ. Prot. Sci. 2007, 1,1-11.

46. Chiu, W.-T.; Ho, Y.-S. Bibliometric analysis of tsunami research. Scientometrics 2007, 73, 3-17. [CrossRef]

47. Kim, H. Notational analysis of sports using social network analysis. Korean J. Meas. Eval. Phys. Educ. Sport Sci. 2007, 9, 99-112.

48. Leydesdorff, L. The university-industry knowledge relationship: Analyzing patents and the science base of technologies. J. Am. Soc. Inf. Sci. Technol. 2004, 55, 991-1001. [CrossRef]

49. Leydesdorff, L.; Hellsten, I. Metaphors and diaphors in science communication mapping the case of stem cell research. Sci. Commun. 2005, 27, 64-99. [CrossRef]

50. Leydesdorff, L.; Welbers, K. The semantic mapping of words and co-words in contexts. J. Inf. 2011, 5, 469-475. [CrossRef]

51. Fig, F. Statement on the Cadastre. International Federation of Surveyors. Available online: http://www.fig. net/resources/publications/figpub/pub11/figpub11.asp (accessed on 5 December 2019).

52. Enemark, S. Global Trends in Land Administration. In Proceedings of the First International Conference of the Arab Union of Surveyors, Beirut, Lebanon, 29 June-1 July 2009.

53. Williamson, I.P.; Enemark, S.; Wallace, J. Sustainability and Land Administration Systems. In Proceedings of the Expert Group Meeting, Melbourne, VIC, Australia, 9-11 November 2005.

54. Bennett, R.; Wallace, J.; Williamson, I. Integrated land administration in Australia: The need to align ICT strategies and operations. In Proceedings of the SSC 2005 Spatial Intelligence, Innovation and Praxis: The national biennial Conference of the Spatial Sciences Institute, September 2005; Spatial Sciences Institute: Melbourne, VIC, Australia, 2005.

55. Kobayashi, S.; Fujioka, T.; Tanaka, Y.; Inoue, M.; Niho, Y.; Miyoshi, A. A geographical information system using the google map API for guidance to referral hospitals. J. Med. Syst. 2010, 34, 1157-1160. [CrossRef] [PubMed]

56. Purves, R.; Jones, C. Geographic Information Retrieval (GIR). Comput. Environ. Urban Syst. 2006, 30, 375-377. [CrossRef]

57. Derbal, K.; Bordogna, G.; Pasi, G.; Alimazighi, Z. Spatial querying supported by domain and user ontologies: An approach for web GIS applications. Adv. Intell. Syst. Comput. 2016, 400, 353-365. [CrossRef]

58. Brown, G.; Kelly, M.; Whitall, D. Which 'public'? Sampling effects in public participation GIS (PPGIS) and volunteered geographic information (VGI) systems for public lands management. J. Environ. Plan. Manag. 2014, 57, 190-214. [CrossRef]

59. Ballatore, A.; Bertolotto, M.; Wilson, D.C. Geographic knowledge extraction and semantic similarity in OpenStreetMap. Knowl. Inf. Syst. 2013, 37, 61-81. [CrossRef]

60. McNeill, G.; Bright, J.; Hale, S.A. Estimating local commuting patterns from geolocated Twitter data (Open Access). EPJ Data Sci. 2017, 6, 24. [CrossRef]

61. Liu, Y.; Wang, F.; Xiao, Y.; Gao, S. Urban land uses and traffic 'source-sink areas': Evidence from GPS-enabled taxi data in Shanghai. Landsc. Urban Plan. 2012, 106, 73-87. [CrossRef]

62. Haklay, M. How good is volunteered geographical information? A comparative study of OpenStreetMap and ordnance survey datasets. Environ. Plan. B 2010, 37, 682-703. [CrossRef]

63. Mashhadi, A.; Quattrone, G.; Capra, L. The impact of society on volunteered geographic information: The case of OpenStreetMap. Lect. Notes Geoinf. Cartogr. 2015, 9783319142791, 125-141. [CrossRef] 
64. Senaratne, H.; Mobasheri, A.; Ali, A.L.; Capineri, C.; Haklay, M. A review of volunteered geographic information quality assessment methods. Int. J. Geogr. Inf. Sci. 2017, 31, 139-167. [CrossRef]

65. Williamson, I. Appropriate cadastral systems. Aust. Surv. 1995, 40, 57-59. [CrossRef]

66. De Meyere, J.C. Cadastral reform in Argentina-An opportunity for system development. Geomat. Info Mag. 1995, 9, 28-30.

67. Fourie, C.; van Gysen, H. Constructing cadastral reform theory in South Africa. Geomatica 1995, 49, 315-328.

68. Williamson, I.P. Land administration "best practice" providing the infrastructure for land policy implementation. J. Land Use Policy 2001, 18, 297-307. [CrossRef]

69. Williamson, I.P. Re-engineering land administration systems for sustainable development- from rhetoric to reality. Int. J. Appl. Earth Obs. Geoinf. 2001, 3, 278-289. [CrossRef]

70. Steudler, D. Swiss cadastral surveyors' response to the LIS/GIS challenge. Geomat. Info Mag. 1995, 9, 30-33.

71. Ofat, H.; Kalantari, M.; Rajabifard, A.; Williamson, I. Towards a foundation for spatial metadata automation. J. Spat. Sci. 2012, 57, 65-81. [CrossRef]

72. Benhamu, M.; Doytsher, Y. Toward a spatial 3D cadastre in Israel, Computers. Environ. Urnan Syst. 2003, 27, 359-374. [CrossRef]

73. Stoter, J.E.; van Oosterom, P. 3D Cadastre in an International Context: Legal, Organizational, and Technological Aspects; Taylor\&Francis: New York, NY, USA, 2006.

74. Williamson, I.P. The future role of the cadastre. In Proceedings of the CIES Korea 2005 Cadastral Innovation Expo and Seminar, Seoul, Korea, 4 May 2005; pp. 8-9.

75. Rajabifard, A.; Binns, A.; Masser, I.; Williamson, I. The role of sub-national government and the private sector in future spatial data infrastructures. Int. J. Geogr. Inf. Sci. 2006, 20, 727-741. [CrossRef]

76. Lemmen, C.; Van Oosterom, P.; Zevenbergen, J.; Quak, W. Further progress in the development of a core cadastral domain model. In Proceedings of the FIG Working Week, Paris, France, 13-17 April 2003.

77. Kalantari, M.; Rajabifard, A.; Wallace, J.; Williamson, I. An interoperability toolkit for e-Land administration. In Sustainability and Land Administration Systems; Department of Geomatics: Melbourne, VIC, Australia, 2006; pp. 213-222.

78. Goodchild, M.F. Citizens as sensors: The world of volunteered geography. GeoJournal 2007, 69, $211-221$. [CrossRef]

79. Spirou-Sioula, K.; Ioannidis, C.; Potsiou, C. Technical aspects for 3D hybrid cadastral model. Surv. Rev. 2013, 45, 419-427. [CrossRef]

80. Yang, C.S. Development of the process of coordinate transformation of local datum cadastral map to the World Geodetic System-Using adjusted coordinate. J. Korean Soc. Surv. Geod. Photogramm. Cartogr. 2014, 32, 401-412. [CrossRef]

81. De Vries, W.T.; Bennett, R.M.; Zevenbergen, J.A. Neo-cadastres: Innovative solution for land users without state based land rights, or just reflections of institutional isomorphism? Surv. Rev. 2015, 47, 220-229. [CrossRef]

82. D'Haeseleer, P.; Liang, S.; Somogyi, R. Genetic network inference: From co-expression clustering to reverse engineering. Bioinformatics 2000, 16, 707-726. [CrossRef] [PubMed]

83. Carmona, A.; Nahuelhual, L.; Echeverría, C.; Báez, A. Linking farming systems to landscape change: An empirical and spatially explicit study in southern Chile. Agric. Ecosyst. Environ. 2010, 139, 40-50. [CrossRef]

84. Andrieu, E.; Ladet, S.; Heintz, W.; Deconchat, M. History and spatial complexity of deforestation and logging in small private forests. Landsc. Urban Plan. 2011, 103, 109-117. [CrossRef]

85. Smith, D.A.; Herlihy, P.H.; Kelly, J.H.; Viera, A.R. The certification and privatization of indigenous lands in Mexico. J. Lat. Am. Geogr. 2009, 8, 175-207. [CrossRef]

86. Gridan, M.; Jianu, S.; Grecea, C. Implication of forestry cadastre in the national strategy of environmental protection. J. Environ. Prot. Ecol. 2012, 13, 2283-2290.

87. Masser, I.; Rajabifard, A.; Williamson, I. Spatially enabling governments through SDI implementation. Int. J. Geogr. Inf. Sci. 2008, 22, 5-20. [CrossRef]

88. Mohammadi, H.; Rajabifard, A.; Williamson, I. Development of an interoperable tool to facilitate spatial data integration in the context of SDI. Int. J. Geogr. Inf. Sci. 2010, 24, 487-505. [CrossRef]

89. Williamson, I.P.; Enemark, S.; Wallace, J.; Rajabifard, A. Land Administration for Sustainable Development; ESRI Press: Academic Redlands, CA, USA, 2010. 
90. Bennett, R.; Rajabifard, A.; Kalantari, M.; Wallace, J.; Williamson, I. Cadastral futures: Building a new vision for the nature and role of cadastres. In Proceedings of the XXIV FIG International Congress, Sydney, NSW, Australia, 11-15 April 2010.

91. Steudler, D.; Rajabifard, A. Spatially Enabled Society. In Proceedings of the International Federation of Surveyors (FIG): Copenhagen, the Spatial Science Institute Biennial Conference, Melbourne, VIC, Australia, 12-16 September 2012.

(c) (i)

(C) 2020 by the author. Licensee MDPI, Basel, Switzerland. This article is an open access article distributed under the terms and conditions of the Creative Commons Attribution (CC BY) license (http://creativecommons.org/licenses/by/4.0/). 